\title{
Intake, physiological parameters and behavior of Angus and Nellore bulls subjected to heat stress
}

\section{Consumo, parâmetros fisiológicos e comportamento de tourinhos Angus e Nelore submetidos a estresse por calor}

\author{
Ériton Egidio Lisboa Valente ${ }^{1 *}$; Mario Luiz Chizzotti²; \\ Cristhiane Viol Ribeiro de Oliveira ${ }^{3}$; Matheus Castilho Galvão ${ }^{3}$; \\ Silas Sebastião Domingues ${ }^{4}$; Aline de Castro Rodrigues ${ }^{3}$; Márcio Machado Ladeira ${ }^{5}$
}

\begin{abstract}
Genetics differences between breeds may determine the tolerance to high temperature, effect dry matter intake and consequently cattle performance. The effect of temperature and humidity index (THI) on diurnal, nocturnal and daily intake, water intake, physiologic parameters and behavior of Nellore $(B$. indicus) and Angus (B. taurus) bulls were evaluated. Eight Angus and eight Nellore young bulls ( $337 \pm 7.4$ $\mathrm{kg}$ and 16 months of age) were allocated in two climate-controlled rooms for 32 days. In the period 1 , all bulls were housed in thermoneutral conditions $(\mathrm{TN}, \mathrm{THI}=72.6)$ for 10 days. In period 2 (10 days), four Angus and four Nellore bulls were subjected to low heat stress (LHS, THI $=76.4$ ) in daytime, and four Angus and four Nellore bulls were subjected to high heat stress (HHS, THI $=81.5$ ) in daytime. The diurnal and daily dry matter intake (DMI) of Nellore were not affected $(\mathrm{P}>0.05)$ by heat stress. However, Angus bulls decreased diurnal DMI by $24 \%$ and daily DMI decreased $(\mathrm{P}<0.05)$ by $15 \%$ on HHS. In TN Angus bulls had higher $(\mathrm{P}<0.05)$ daily DMI $(36.2 \mathrm{~g} / \mathrm{kg}$ of BW) than Nellore $(29.1 \mathrm{~g} / \mathrm{kg}$ of BW), but in HHS they had similar ( $\mathrm{P}>0.05$ ) daily DMI (31.6 and $30.2 \mathrm{~g} / \mathrm{kg}$ of $\mathrm{BW}$, respectively). We observed an increase $(\mathrm{P}<0.05)$ in respiratory frequency, but water intake was not affected $(\mathrm{P}>0.05)$ by heat stress. The heart rate decreased $(\mathrm{P}<0.05)$ with heat stress. No differences were found $(\mathrm{P}>0.05)$ in feeding behavior. Therefore, THI stress threshold should distinct for Angus and Nellore bulls. The use of feed intake information may improve the prediction of thermic discomfort on specific climate condition.
\end{abstract}

Key words: Beef cattle, intake regulation, temperature

\section{Resumo}

Diferenças genéticas entre raças podem determinar a tolerância a temperaturas elevadas, afetar o consumo de alimentos e consequentemente o desempenho de bovinos. Avaliou-se o efeito do índice de temperatura e umidade (ITU) sobre o consumo diurno, noturno e diário de matéria seca (MS), ingestão diária de água, parâmetros fisiológicos e comportamento de tourinhos da raça Nelore (Bos indicus) e da raça Angus (Bos taurus). Foram utilizados oito tourinhos da raça Nelore e da raça oito Angus ( $337 \pm 7,4 \mathrm{~kg}$ e 16 meses de idade) alocados em duas salas climatizadas por 32 dias. No primeiro período, todos os tourinhos

\footnotetext{
${ }^{1}$ Prof. Dr., Universidade Estadual do Oeste do Paraná, UNIOESTE, Marechal Cândido Rondon, PR, Brasil. E-mail: eritonvalente@ yahoo.com.br

2 Prof. Dr., Universidade Federal de Viçosa, UFV, Viçosa, MG, Brasil. E-mail: mariochizzotti@gmail.com

${ }^{3}$ Discentes de Zootecnia, Universidade Federal de Lavras, UFLA, Lavras, MG, Brasil. E-mail: cris_viol@yahoo.com.br; matheuscgalvao@hotmail.com; alinecrodrigue@hotmail.com;

4 Discente de Mestrado em Zootecnia, UFLA, Lavras, MG, Brasil. E-mail: silasufla@hotmail.com

${ }^{5}$ Prof. Dr., UFLA, Lavras, MG, Brasil. E-mail: mladeira@dzo.ufla.br

* Author for correspondence
} 
foram alojados em condições de termoneutralidade $(\mathrm{TN}, \mathrm{ITU}=72,6)$ por 10 dias. No segundo período (10 dias) quatro tourinhos da raça Angus e quatro da raça Nelore foram submetidos a baixo estresse por calor $(\mathrm{BEC}, \mathrm{ITU}=76,4)$ durante o dia e quatro tourinhos Angus e quatro Nelore foram submetidos a alto estresse por calor $(\mathrm{AEC}, \mathrm{ITU}=81,5)$ durante o dia. O consumo diurno e diário de matéria seca $(\mathrm{MS})$ dos animais da raça Nelore não foi afetado $(\mathrm{P}>0,05)$ pelo estresse calórico. No entanto, os tourinhos da raça Angus reduziram o CMS diurno em $24 \%$ e a CMS diário reduziu $(\mathrm{P}<0,05)$ em $15 \%$ sob AEC. No TN, os animais da raça Angus apresentaram maior $(\mathrm{P}<0,05)$ CMS diário $(36,2 \mathrm{~g} / \mathrm{kg}$ de $\mathrm{PC})$ que os da raça Nelore (29,1 g / kg do PC), mas em AEC eles tiveram (P>0,05) CMS semelhantes (31,6 e 30,2 g / kg do $\mathrm{PC}$, respectivamente). Observou-se aumento $(\mathrm{P}<0,05)$ na frequência respiratória, mas a ingestão de água não foi afetada $(\mathrm{P}>0,05)$ pelo estresse calórico. A Frequência cardíaca diminuiu $(\mathrm{P}<0,05)$ com o estresse calórico. Não foi observado efeito do ITU $(\mathrm{P}>0,05)$ sobre o comportamento alimentar. Portanto, recomenda-se o uso de intervalos distintos de ITU para indicar segurança térmica em tourinhos das raças Angus e Nelore. O uso de informações de consumo em conjunto com as variáveis climáticas pode melhorar a predição de desconforto térmico em condições climáticas específicas.

Palavras-chave: Bovinos de corte, regulação do consumo, temperatura

\section{Introduction}

Over the last decade, livestock production has considerably expanded in tropical and subtropical countries in order to meet a rising population, international meat exchanges and consumer demand. Despite many challenges facing animal producers including environmental challenging, it is still predicted that livestock production in developing countries will continue to sustain the future growth of the world's meat production (RENAUDEAU et al., 2010). In most production systems livestock are constantly confronted with short and longterm changes caused by a wide range of climatic factors (SEJIAN et al., 2011), and they need to use mechanisms to keep the internal temperature in appropriate physiology level.

Environmentally induced hyperthermia decreases efficiency and production (O'BRIEN et al., 2010; RENAUDEAU et al., 2012). One of the first noticeable production signs of heat stress (HS) is reduced feed intake, which is presumably an evolutionary strategy to reduce the "heat increment" of feeding (O'BRIEN et al., 2010).

Initial responses of animals in a heat stress situation are considered homeostatic mechanisms and include increased water intake, sweating and respiration rates and reduced heart rate and feed intake (HOROWITZ, 2002). In hot climate, the adoption of adapted cattle breeds may contribute for farm productivity. However, the knowledge of breed's tolerance to high temperatures may indicate how proceed in modification of farm structures and feeding management to improve acclimation and increase productivity.

The temperature and humidity index (THI) has been used for many decades to assess heat stress in cattle. Although studies has showed different THI value to indicate heat stress for Bos Taurus and Bos indicus (GAUGHAN et al., 2008), behavior and intake are not usually considered together with climatic variables for evaluate effect of heat stress.

There have been few studies that compare the specific thermoregulatory abilities of $B$. indicus and $B$. taurus, and the effect of heat stress in daytime on diurnal and nocturnal intake is currently unknown. Thus, the objective of this study was to evaluate the effect of temperature and humidity index (THI) on diurnal, nocturnal and daily intake, water intake, feeding behavior and physiological parameters in Nellore (B. indicus) and Angus (B. taurus) bulls.

\section{Material and Methods}

The experimental protocol and procedures were approved by the Universidade Federal de Lavras Animal Care and Use Committee n. 068/12. 
The study was conducted in two climatecontrolled rooms (CCR) at Universidade Federal de Lavras, Minas Gerais, Brazil, between October and November of 2012. Sixteen bulls, eight Angus and eight Nellore with initial average BW of $337 \pm$ $7.4 \mathrm{~kg}$ at 16 months of age were used. Eight bulls (four Angus and four Nellore) were individually penned in each room. Each bull had a pen space of $3.75 \mathrm{~m}^{2}$ and individual access to a feeder and water bucket. A photoperiod of $12 \mathrm{~h}$ x $12 \mathrm{~h}$ was used. The physiologic parameters evaluated were heart rate $(\mathrm{HR})$, respiration frequency (RF) and skin and eye temperatures.

The experiment was carried out in two periods of $10 \mathrm{~d}$ each, starting after $10 \mathrm{~d}$ adaptation to the CCR and diet. In period 1 , both CCR were kept at average daytime temperatures of $25^{\circ} \mathrm{C}$ (thermoneutral ambient, $\mathrm{TN}$ ) and temperature humidity index (THI) of 72.6. In period 2, one CCR was kept with average temperature of daytime (06h00 to $18 \mathrm{~h} 00$ ) at $29^{\circ} \mathrm{C}$ and THI of 76.4 (low heat stress, LHS) and another at $33^{\circ} \mathrm{C}$ and THI of 81.5 (high heat stress, HHS). At night (18h00 to 06h00) both CCR were kept at $25^{\circ} \mathrm{C}$. The transition from period 1 (thermo-neutral) to period 2 (daytime heat stress) was accomplished over an additional 2-day period, increasing $2^{\circ} \mathrm{C}$ per day for LHS and $4^{\circ} \mathrm{C}$ for HHS treatments.

The bulls were weighed at the beginning and at the end of the experimental period without fasting. The diet was composed of $50 \%$ of corn silage and $50 \%$ of concentrate ( $82 \%$ ground corn grain, $16 \%$ soybean meal and $2 \%$ mineral mixed) offered ad libitum. Water was available for ad libitum consumption.

The diet was offered twice daily, $06 \mathrm{~h} 00$ and 18h00. The orts were withdrawn before each feeding and samples were collected to evaluate dry matter intake (DMI). The amount of feed offered in each period of day was calculated using the corresponding previous orts to ensure $10 \%$ orts. The water buckets (volume of 201) were weighed and refilled daily at $06 \mathrm{~h} 00,12 \mathrm{~h} 00$ and $18 \mathrm{~h} 00$ to evaluate water consumption.

Environmental conditions (temperature and relative humidity) were daily measured at $06 \mathrm{~h} 00$, 10h00, $14 \mathrm{~h} 00$ and $18 \mathrm{~h} 00$. The temperature and humidity index (THI) was calculated from the air temperature $\left(\mathrm{T}_{\mathrm{A}},{ }^{\circ} \mathrm{C}\right)$ and relative humidity $(\mathrm{RH}, \%)$ according to Gaughan et al. (2013): THI $=\left(0.8 \times \mathrm{T}_{\mathrm{A}}\right)$ $\left.+\left[(\mathrm{RH} \times 0.01) \times\left(\mathrm{T}_{\mathrm{A}}-14.4\right)\right]+46.4\right)$.

Heart rate (HR) was obtained in $\mathrm{d} 9$ and $\mathrm{d} 10$ of each period only in Angus bulls at intervals of $1 \mathrm{~min}$ for 48 hours using heart rate monitors (Polar RS800, Finland). The Nellore cattle did not adapt to heart rate monitors, as they became excessively excited, and HR could not be measured in them. Respiration frequency (RF) was obtained in days 9 and 10 of each period by counting flank movement at 1-min intervals for 4 different times $(06 \mathrm{~h} 00$, $10 \mathrm{~h} 00,14 \mathrm{~h} 00$ and $18 \mathrm{~h} 00$ ) per day (BEATTY et al., 2006; O'BRIEN et al., 2010).

In reason of the difficulty to obtain precise body temperature values without excited the bulls, infrared thermography (Fluke Corporation, USA) of the eyes were used to indicate core temperature (JOHNSON et al., 2011) and temperatures of a specific area on the animal's face to indicate skin temperature (MONTANHOLI et al., 2010). Eye and skin temperatures were obtained on d 10 of each period at $15 \mathrm{~h} 00$. The skin temperature was the average of temperature of a specific area on the bull's face (similar area of eye ball projected in the face immediately under the eyes).

The behavior was evaluated using 24-hour video recording with night vision cameras on $\mathrm{d}$ 6 and $\mathrm{d} 7$ of each period in both CCR. The time spent with feed intake, standing and lying down was continuously measured (every each second).

Samples of silage and concentrate were analyzed for dry matter (DM, index no. 920.39), nitrogen compounds (index no. 954.01) and ashes (index no. 923.03) as described by AOAC (1990), and neutral 
detergent fiber (MERTENS, 2002). The ort samples were analyzed for DM content as described before.

Feed intake was analyzed as diurnal intake (06h00 to $18 \mathrm{~h} 00)$, as nocturnal intake (18h00 to $06 \mathrm{~h} 00)$ and as daily intake (06h00 to $06 \mathrm{~h} 00)$. Water intake was measured as intake in 24 hours. The other variables analyzed were $\mathrm{HR}, \mathrm{RF}$, and temperature of eye and skin.

The variables were evaluated according to a completely randomized design with repeated measures over time using the mixed models method according to:

$$
Y_{i j k}=\mu+H_{i}+a_{j}+G_{j}+(H \times G)_{j}+\varepsilon_{i j k}
$$

where Yijk is the response variable measured in the experimental unit $\mathrm{k}$ submitted to the $\mathrm{i}$ heat stress in the $\mathrm{j}$ genetic group; $\mu$ is the overall constant; Hi is the effect of the $\mathrm{i}$ heat stress (fixed effect); aij = effect of animal $\mathrm{j}$ within heat stress $\mathrm{i}$ (random effect); $\mathrm{Gj}$ is the effect of $\mathrm{j}$ genetic group (fixed effect); $(\mathrm{HxG}) \mathrm{ij}$ is the interaction between the principal effects (fixed effect); and eijk is the non-observable random error, presupposed with normal distribution.

The best structures of the matrix of covariance (VC) were defined by using Akaike's information criteria. Differences were considered significant at $\mathrm{P}<0.05$. The data were analyzed using the MIXED procedure of SAS version 9.1 (SAS Institute, Inc).

\section{Results}

The diet composition was: dry matter $=$ $59.7 \%$; organic matter $=55.9 \%$; crude protein $=$ $11.6 \%$; neutral detergent fiber $=34 \%$; non-fibrous carbohydrate $=47.1 \%$. In attempt to simulate the normal cycle of temperature along the 24-hours, the temperature in climatic chamber were progressively increased from $06 \mathrm{~h} 00$ until $14 \mathrm{~h} 00$, was stabilized until $18 \mathrm{~h} 00$ and progressively decreased after this (Figure 1). In hottest time of day, temperature reached $28.9 \pm 0.3^{\circ} \mathrm{C}$ (THI of 76.6) and $33.2 \pm$ $0.3^{\circ} \mathrm{C}$ (THI of 84.7) in LHS and HHS, respectively (Table 1). In the heat stress treatments, the THI consistently increased reaching heat stress categories (GAUGHAN et al., 2013) of alert (THI of 75-78) in LHS in diurnal period and danger category (THI of 79-83) in HHS with peaks reaching the emergency category $(>84)$ in some hours in the diurnal period (Table 1). However, in thermoneutral temperatures and at night for all treatments, the THI was close to normal category $(<74)$. The average temperature of water available for the bulls was kept between 21 and $24^{\circ} \mathrm{C}$ in all treatments.

There was no interaction $(\mathrm{P}>0.05)$ between breeds and heat stress. Diurnal and daily DMI by Nellore bulls was not affected ( $\mathrm{P}>0.05$ ) by LHS nor HHS. However, an increase $(\mathrm{P}<0.05)$ in DMI in the nocturnal period with LHS was observed compared to the thermo-neutral environment. In addition, on HHS conditions, the nocturnal DMI was similar $(\mathrm{P}>0.05)$ to the thermoneutral conditions. Although Angus bulls had no difference $(\mathrm{P}>0.05)$ in nocturnal DMI on heat stress, the diurnal DMI decreased 24\% $(\mathrm{P}<0.05)$ and daily DMI decreased $15 \%$ on HHS $(\mathrm{P}<0.05)$.

Angus bulls had higher daily DMI (36.2 g/kg of BW) than Nellore ones $(29.1 \mathrm{~g} / \mathrm{kg}$ of BW) on $\mathrm{TH}$ $(\mathrm{P}<0.05)$, but in HHS they had similar $(\mathrm{P}<0.05)$ daily DMI (31.6 and $30.2 \mathrm{~g} / \mathrm{kg}$ of BW, respectively; Table 2). On LHS Angus bulls had higher diurnal DMI $(\mathrm{P}<0.05)$ and similar nocturne DMI $(\mathrm{P}>0.05)$ in comparison with Nellore bulls. However, on HHS both diurnal and nocturne DMI were similar $(\mathrm{P}>0.05)$ between Angus and Nellore bulls. No differences were observed ( $\mathrm{P}>0.05)$ in water intake with the increase of THI. However, Angus bulls had higher $(\mathrm{P}>0.05)$ water intake than Nellore bulls for all treatments. 
Table 1. Average, minimum and maximum temperature and relative humidity ( \pm SE) for each climate-controlled rooms at day (06h00 to $18 \mathrm{~h} 00)$ and at night (18h00 to $06 \mathrm{~h} 00)$.

\begin{tabular}{|c|c|c|c|c|c|c|c|c|}
\hline \multirow{4}{*}{ Item } & \multicolumn{4}{|c|}{ Period 1} & \multicolumn{4}{|c|}{ Period 2} \\
\hline & \multirow{2}{*}{\multicolumn{2}{|c|}{$\begin{array}{c}\text { Thermoneutral } \\
\text { CCR } 1\end{array}$}} & \multirow{2}{*}{\multicolumn{2}{|c|}{$\begin{array}{c}\text { Thermoneutral } \\
\text { CCR2 }\end{array}$}} & \multirow{2}{*}{\multicolumn{2}{|c|}{$\begin{array}{l}\text { Low heat stress } \\
\text { CCR } 1\end{array}$}} & \multirow{2}{*}{\multicolumn{2}{|c|}{$\begin{array}{c}\text { High heat stress } \\
\text { CCR2 }\end{array}$}} \\
\hline & & & & & & & & \\
\hline & Day & Night & Day & Night & Day & Night & Day & Night \\
\hline \multicolumn{9}{|c|}{ Temperature $\left({ }^{\circ} \mathrm{C}\right)$} \\
\hline Average & $25.2 \pm 0.5$ & $25.2 \pm 0.3$ & $25.3 \pm 0.3$ & $25.6 \pm 0.3$ & $28.6 \pm 0.2$ & $25.8 \pm 0.3$ & $31.8 \pm 0.4$ & $25.8 \pm 0.2$ \\
\hline Minimum & $23.4 \pm 0.7$ & $23.4 \pm 0.7$ & $24.3 \pm 0.8$ & $24.2 \pm 0.8$ & $27.8 \pm 0.3$ & $25.2 \pm 0.3$ & $29.2 \pm 0.3$ & $25.12 \pm 0.5$ \\
\hline Maximum & $26.5 \pm 0.3$ & $26.9 \pm 0.7$ & $26.4 \pm 0.3$ & $25.8 \pm 0.8$ & $28.9 \pm 0.2$ & $26.9 \pm 0.3$ & $33.2 \pm 0.3$ & $27.6 \pm 0.4$ \\
\hline \multicolumn{9}{|c|}{ Relative humidity (\%) } \\
\hline Average & $54.8 \pm 1.2$ & $54.4 \pm 1.4$ & $54.5 \pm 0.9$ & $53.7 \pm 1.2$ & $61.7 \pm 1.2$ & $61.0 \pm 2.3$ & $64.9 \pm 1.0$ & $64.1 \pm 1.5$ \\
\hline Minimum & $47.6 \pm 1.0$ & $44.7 \pm 1.8$ & $50.3 \pm 2.1$ & $47.5 \pm 1.7$ & $58.6 \pm 2.8$ & $52.0 \pm 2.0$ & $61.5 \pm 2.4$ & $55.4 \pm 2.7$ \\
\hline Maximum & $60.3 \pm 1.6$ & $65.4 \pm 0.6$ & $57.7 \pm 1.4$ & $62.4 \pm 0.6$ & $65.1 \pm 2.4$ & $69.2 \pm 3.1$ & $65.8 \pm 1.4$ & $73.2 \pm 3.1$ \\
\hline \multicolumn{9}{|c|}{ Temperature and humidity index } \\
\hline Average & $72.6 \pm 0.4$ & $72.3 \pm 0.3$ & $72.6 \pm 0.5$ & $72.5 \pm 0.4$ & $76.4 \pm 0.7$ & $74.5 \pm 0.4$ & $81.5 \pm 1.0$ & $74.4 \pm 0.3$ \\
\hline Minimum & $72.2 \pm 1.2$ & $72.2 \pm 1.0$ & $72.1 \pm 0.9$ & $72.2 \pm 1.0$ & $74.7 \pm 1.3$ & $72.5 \pm 1.3$ & $78.8 \pm 1.4$ & $72.2 \pm 0.9$ \\
\hline Maximum & $73.0 \pm 0.5$ & $72.6 \pm 0.7$ & $73.0 \pm 0.9$ & $72.6 \pm 0.9$ & $76.6 \pm 1.6$ & $74.6 \pm 1.3$ & $84.7 \pm 0.4$ & $75.5 \pm 0.7$ \\
\hline
\end{tabular}

Table 2. Effect of heat stress (means and SE) on diurnal ( $06 \mathrm{~h} 00$ to $18 \mathrm{~h} 00)$, nocturne ( $18 \mathrm{~h} 00$ to $06 \mathrm{~h} 00)$ and daily dry matter intake (DMI), and water intake according of genetic group.

\begin{tabular}{|c|c|c|c|c|c|}
\hline \multirow{2}{*}{ Genetic group } & \multicolumn{3}{|c|}{ Treatment } & \multirow{2}{*}{ SE } & \multirow{2}{*}{ P-value } \\
\hline & Thermoneutral & Low heat stress & High heat stress & & \\
\hline & \multicolumn{3}{|c|}{ Diurnal DMI $\left(\mathrm{g} \mathrm{kg}^{-1}\right.$ of BW) } & & \\
\hline Angus & $18.1 \mathrm{Aa}$ & $16.5 \mathrm{Aa}$ & $14.1 \mathrm{~b}$ & 0.47 & $<0.001$ \\
\hline Nellore & $14.0 \mathrm{~B}$ & $12.6 \mathrm{~B}$ & 13.6 & 0.47 & 0.178 \\
\hline SE & 0.37 & 0.50 & 0.50 & & \\
\hline \multirow[t]{2}{*}{ P-value } & $<0.001$ & 0.001 & 0.604 & & \\
\hline & \multicolumn{3}{|c|}{ Nocturne DMI ( $\mathrm{g} \mathrm{kg}^{-1}$ of BW) } & & \\
\hline Angus & $18.2 \mathrm{~A}$ & 19.0 & 17.3 & 0.56 & 0.266 \\
\hline Nellore & $15.2 \mathrm{Bb}$ & $17.2 \mathrm{a}$ & $16.6 \mathrm{ab}$ & 0.56 & 0.012 \\
\hline SE & 0.43 & 0.55 & 0.55 & & \\
\hline \multirow[t]{2}{*}{ P-value } & 0.003 & 0.111 & 0.493 & & \\
\hline & \multicolumn{3}{|c|}{ Daily DMI $\left(\mathrm{g} \mathrm{kg}^{-1}\right.$ of BW) } & & \\
\hline Angus & $36.2 \mathrm{Aa}$ & $35.4 \mathrm{Aa}$ & $31.6 \mathrm{~b}$ & 0.71 & 0.003 \\
\hline Nellore & $29.1 \mathrm{~B}$ & $29.8 \mathrm{~B}$ & 30.2 & 0.71 & 0.504 \\
\hline SE & 0.67 & 0.95 & 0.95 & & \\
\hline \multirow[t]{2}{*}{ P-value } & $<0.001$ & 0.003 & 0.439 & & \\
\hline & \multicolumn{3}{|c|}{ Water intake $\left(\mathrm{kg} \mathrm{day}^{-1}\right)$} & & \\
\hline Angus & $25.0 \mathrm{~A}$ & $24.7 \mathrm{~A}$ & $22.7 \mathrm{~A}$ & 0.76 & 0.253 \\
\hline Nellore & $15.9 \mathrm{~B}$ & $16.7 \mathrm{~B}$ & $18.0 \mathrm{~B}$ & 0.76 & 0.185 \\
\hline SE & 0.72 & 1.01 & 1.01 & & \\
\hline P-value & $<0.001$ & $<0.001$ & 0.010 & & \\
\hline
\end{tabular}

Different subscript lowercase letters within a row and different subscript capital letters within a column denote significant difference $(\mathrm{P}<0.05)$. 
Although eye temperature and skin temperature were similar $(\mathrm{P}>0.05)$ for LHS and HHS, they were higher $(\mathrm{P}<0.05)$ than at TN for both genetic groups. Respiration frequency (RF) were also similar between LHS and HHS $(\mathrm{P}>0.05)$, and were higher $(\mathrm{P}<0.05)$ than at TN for both genetic groups. However, Angus bulls had higher $(\mathrm{P}<0.05) \mathrm{RF}$ than Nellore on LHS, HHS, and even in $\mathrm{TN}\left(25^{\circ} \mathrm{C}\right)$. Angus bulls on HHS had a decrease of $6 \%$ in $\mathrm{HR}(\mathrm{P}<0.05)$, while the RF increased by $20 \%(\mathrm{P}<0.05$, Table 3$)$.

Table 3. Effect of heat stress (means and SE) on heart rate, Respiration frequency, eye temperature and skin temperature according of genetic group.

\begin{tabular}{|c|c|c|c|c|c|}
\hline \multirow{2}{*}{ Genetic group } & \multicolumn{3}{|c|}{ Treatment } & \multirow{2}{*}{ SE } & \multirow{2}{*}{ P-value } \\
\hline & Thermoneutral & Low heat stress & High heat stress & & \\
\hline & \multicolumn{3}{|c|}{ Heart rate (beats. minute ${ }^{-1}$ ) } & & \\
\hline Angus & $93.0 \mathrm{a}$ & $89.9 \mathrm{ab}$ & $87.0 \mathrm{~b}$ & 1.21 & 0.046 \\
\hline Nellore & - & - & - & - & \\
\hline SE & 1.61 & 2.46 & 2.13 & & \\
\hline \multirow[t]{2}{*}{ P-value } & - & - & - & & \\
\hline & \multicolumn{3}{|c|}{ Respiration frequency (breaths minutes ${ }^{-1}$ ) } & & \\
\hline Angus & $86.3 \mathrm{Ab}$ & $96.8 \mathrm{Aa}$ & $104.0 \mathrm{Aa}$ & 1.83 & $<0.001$ \\
\hline Nellore & $29.5 \mathrm{Bb}$ & $42.0 \mathrm{Ba}$ & $45.2 \mathrm{Ba}$ & 1.95 & 0.003 \\
\hline SE & 1.73 & 2.45 & 2.65 & & \\
\hline \multirow[t]{2}{*}{ P-value } & $<0.001$ & $<0.001$ & $<0.001$ & & \\
\hline & \multicolumn{3}{|c|}{ Eye temperature $\left({ }^{\circ} \mathrm{C}\right)$} & & \\
\hline Angus & $36.5 \mathrm{Ab}$ & $37.4 \mathrm{a}$ & $37.7 \mathrm{Aa}$ & 0.13 & $<0.001$ \\
\hline Nellore & $35.9 \mathrm{Bb}$ & $37.2 \mathrm{a}$ & $36.6 \mathrm{Ba}$ & 0.13 & 0.001 \\
\hline $\mathrm{SE}$ & 0.12 & 0.17 & 0.17 & & \\
\hline \multirow[t]{2}{*}{ P-value } & 0.012 & 0.496 & 0.004 & & \\
\hline & \multicolumn{3}{|c|}{ Skin temperature $\left({ }^{\circ} \mathrm{C}\right)$} & & \\
\hline Angus & $34.3 b$ & $35.9 \mathrm{a}$ & $36.2 \mathrm{a}$ & 0.12 & $<0.001$ \\
\hline Nellore & $34.1 b$ & $35.9 \mathrm{a}$ & $35.6 \mathrm{a}$ & 0.12 & $<0.001$ \\
\hline SE & 0.11 & 0.16 & 0.16 & & \\
\hline $\mathrm{P}$-value & 0.278 & 0.969 & 0.072 & & \\
\hline
\end{tabular}

Different subscript lowercase letters within a row and different subscript capital letters within a column denote significant difference $(\mathrm{P}<0.05)$. It was no possible measure heart rate in Nellore bulls because they did not adapt to the equipment.

Differences were not found $(\mathrm{P}>0.05)$ in diurnal intake time, nocturnal intake time, daily intake time, standing time and lying down time between breeds and between air temperatures (Table 4). The bulls spent an average of 164 minutes/day eating, $54 \%$ of which were during the daytime. 
Table 4. Effect of heat stress (means and SE) on diurnal ( $06 \mathrm{~h} 00$ to $18 \mathrm{~h} 00)$, nocturne (18h00 to $06 \mathrm{~h} 00$ ) and daily intake time (minutes), stand time and lying down time.

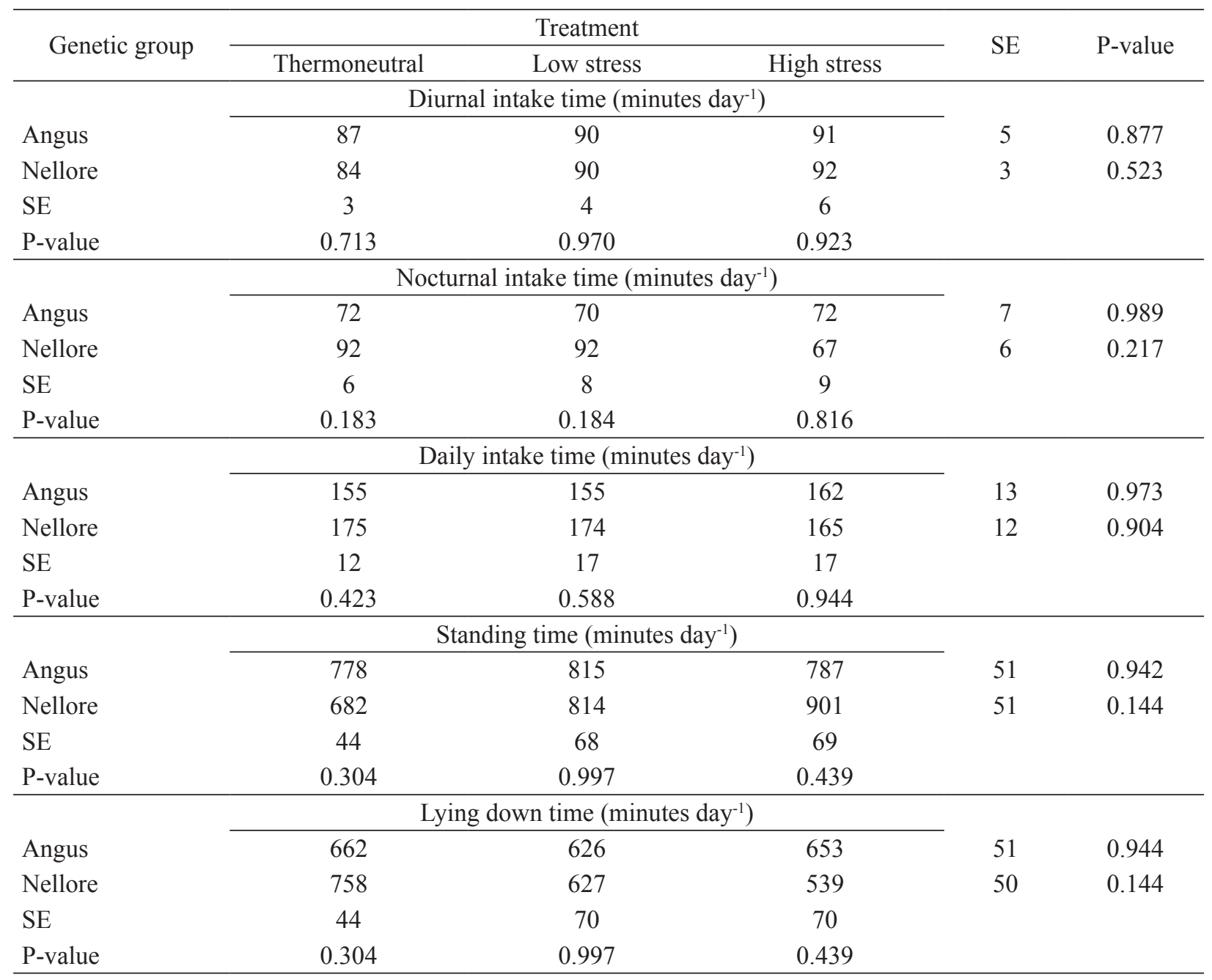

Significant level at $\mathrm{P}<0.05$.

\section{Discuss}

Genetics differences between Angus and Nellore bulls may determine distinct performance even on thermoneutral conditions. Although on TN ambient Bos taurus may have higher production than Bos indicus, on heat stress ambient Bos indicus may have similar or higher production than Bos taurus due to differences in physiological changes to keep adequate core temperature from each breed (BEATTY et al., 2006). Angus and Nellore bulls had differences in nutritional (Table 2) and physiological (Table 3) responses even when at same THI category.
Although neither Nellore nor Angus had decrease of DMI at night, Angus bulls decreased in diurnal and daily DMI on THI of 81.5, probably, in attempt to decrease metabolic heat production (RENAUDEAU et al., 2012). Thus, the higher tolerance to hot climate from Bos indicus compared to Bos taurus (GAUGHAN et al., 2010) allowed Bos indicus maintain DMI even on THI of 81.5. However, at night, when the temperatures were bland, Angus did not change DMI, even when they were on high heat stress at diurnal period.

The differences in anatomical and morphological characteristics partially explain differences in heat 
tolerance among species and breeds (GAUGHAN et al., 2010). Thus, studies have found differences in animal responses on heat stress. Gaughan et al. (2010) reported a reduction in DMI of Bos taurus $\times$ Bos indicus genotypes ranging from 10 to $20 \%$. In addition, O'Brien et al. (2010) observed a decrease in DMI of $12 \%$ to cattle on heat stress. Nellore bulls had similar daily feed intake on heat stress and on thermoneutral ambient. Thus, even on HHS, where the average diurnal temperature was $31.8^{\circ} \mathrm{C}$ with an average peak of $33.2^{\circ} \mathrm{C}$ (THI of 84.7), Nellore bulls were able to maintain their body temperatures at adequate levels without decrease in DMI. On the other hand, Angus bulls did not change daily DMI on THI of 76.4 (LHS), but they had a decrease of $15 \%$ in daily DMI on THI of 81.5 (HHS). Although Angus bulls were able to maintenance nocturnal DMI on HHS, daily DMI decreased due to the strong decrease in diurnal DMI.

Although the decrease in DMI is the most important effect at animal production on heat stress, DMI may only be responsible for $\sim 40-50 \%$ of the decrease in milk production when cows are heat stressed and $\sim 50-60 \%$ can be explained by other changes induced by heat stress (WHEELOCK et al., 2010). Physiological adaptations include changes in basal metabolism, RF, distribution of blood flow to skin and lungs, feed and water consumption, rate of passage of feed through the digestive tract, hair coat, and body composition may alleviate heat stress by reduction of heat load and metabolic heat production, and increase of the body's capacity to eliminate heat. It may also be noted that animals differ greatly in their behavioral responses and in their ability to physiologically adapt to the thermal environment (SCHÜTZ et al., 2014).

Eye temperature, which indicates core temperature(JOHNSON et al., 2011), increased from $\mathrm{TN}$ to heat stress, indicating that the increase in air temperature caused an increase in core temperature. The eye temperature was similar between LHS and HHS; therefore, the bulls were able to maintain the core temperature at appropriate levels by using physiological and behavioral modifications.

During genetic adaptation, Bos indicus cattle have acquired thermo-tolerant genes (HANSEN, 2004) and therefore have a higher degree of thermotolerance compared with Bos taurus. Gaughan et al. (1999) reported that genetic adaptation allows Bos indicus cattle to have lower RF and rectal temperatures than Bos taurus when exposed to similar heat stress conditions.

Respiration frequency during heat exposure increased more rapidly than other responses and often occurred at a lower critical air temperatures than other responses such as rectal temperature or changes in DMI (HAHN, 1999). The fact that Angus cattle had higher RF than Nellore even on TH may be explained by their higher gain rate, which results in increase in metabolic activities and consequently higher heat production.

When homoeothermic animals are on heat stress, they increase mechanisms to heat loss and decrease metabolic rate. Therefore, the decrease of metabolic rate may decrease blood flow demand and, consequently, heart rate (HR). Furthermore, an expanded blood volume, and therefore a greater preload and stroke volume, could also explain the decrease in HR (BEATTY et al., 2006).

Increased water loss via skin and respiratory evaporation (sweating and panting, respectively) in an attempt to dissipate heat can decrease body water levels (BERNABUCCI et al., 2010). Water intake is determined by climatic factors, type of diets, animal breed, and animal body weight, as well as animal physiological status (ARIAS; MADER, 2011). Thompson et al. (2011) demonstrated that Bos taurus are less adapted to hot conditions and may have a greater sweat rate than Bos indicus. Thus, the higher water intake by Angus bulls might be a response from physiologic changes that increases water loss. Therefore two hypothesis, that might occurred simultaneously, may explain the higher water intake of the Angus bulls than Nellore bulls: the first one is that even in TN treatment the Angus 
bulls were not really in thermoneutral condition for the breed and have to increase water intake to maintenance adequate core temperature; the second one is that the higher gain rate and intake demand higher water intake than Nellore bulls.

In traditional concept to evaluate heat stress, same physiologic climatic variables have been considered together. Therefore, if was considered only physiologic variables, THI of 76.4 and 81.5 would be equivalent stressor agent for both genetic group (Table 3). However, Angus bulls had a decrease of $10.7 \%$ in daily DMI on THI of 81.5 in comparison with 76.4 (Table 2) which may have a strong impact in animal performance, while Nellore bulls had not decreases in DMI.

In livestock production systems, nutritional information from cattle is a common concern. On tropical climate, livestock is usually challenged by weather. However, adapted breeds, like Nellore, may modify physiology and behavior characteristics to reach adequate core temperature without changing feed intake and with low impact on performance if heat stress is not overly severe. On the other hand, at the same condition, non-adapted breeds, like Angus, may have a considerable decrease of feed intake and consequently, may have performance lower than their genetic potential.

The time spent with feed intake may be affected by the bite rate, which in turn may be decreased by heat stress (SPRINKLE et al., 2000). In this study no differences were found on feeding behavior with increase of air temperature in both genotypes (Table 4), even occurring decrease of DMI to Angus on heat stress (Table 3). Thus, it may be inferred that the reduction in DMI due to heat stress was followed by decreases in bite rate, and consequently no changes in intake time would be expected. Similarly to TN ambient, in heat stress ambient a substantial portion of feed intake time occurred at night (about $45 \%$ of daily intake time) when air temperature was close to thermoneutral.

\section{Conclusion}

THI stress threshold should be distinct for Angus and Nellore bulls. The use of feed intake information may improve the prediction of thermic discomfort on specific climate condition.

When feed is available in feedlot, beef cattle may consume about half of daily dry matter at night. On heat stress during daytime, DMI at night exceed diurnal intake. Evening feeding may be a strategy to increase daily feed intake in feedlot in hot climates.

\section{Acknowledgements}

The authors thank the Conselho Nacional de Pesquisa e Desenvolvimento Científico e Tecnológico (CNPq) for the financial support.

\section{References}

ARIAS, R. A.; MADER T. L. Environmental factors affecting daily water intake on cattle finished in feedlots. Journal of Animal Science, Champaign, v. 89, n. 1, p. 245-251, 2011.

ASSOCIATION OF OFFICIAL ANALYTICAL CHEMISTS - AOAC. Official methods of analysis. $15^{\text {th }}$ ed. Arlington: AOAC International, 1990.

BEATTY, D. T.; BARNES, A.; TAYLOR, E.; PETHICK, D.; MCCARTHY, M.; MALONEY, S. K. Physiological responses of Bos taurus and Bos indicus cattle to prolonged, continuous heat and humidity. Journal of Animal Science, Champaign, v. 84, n. 4, p. 972-985, 2006.

BERNABUCCI, U.; LACETERA, N.; BAUMGARD, L. H.; RHOADS, R. P.; RONCHI, B.; NARDONE, A. Metabolic and hormonal acclimation to heat stress in domesticated ruminants. Animal, Cambridge, v. 4, n. 7, p. 1167-1183, 2010.

GAUGHAN, J. B.; BONNER, S. L.; LOXTON, I.; MADER, T. L. Effects of chronic heat stress on plasma concentration of secreted heat shock protein 70 in growing feedlot cattle. Journal of Animal Science, Champaign, v. 91, n. 1, p. 120-129, 2013.

GAUGHAN, J. B.; MADER, T. L.; HOLT, S. M.; JOSEY, M. J.; ROWAN, K. J. Heat tolerance of Boran and Tuli crossbred steers. Journal of Animal Science, Champaign, v. 77, n. 9, p. 2398-2405, 1999. 
GAUGHAN, J. B.; MADER, T. L.; HOLT, S. M.; LISLE, A. A new heat load index for feedlot cattle. Journal of Animal Science, Champaign, v. 86, n. 1, p. 226-234, 2008.

GAUGHAN, J. B.; MADER, T. L.; HOLT, S. M.; SULLIVAN, M. L.; HAHN, G. L. Assessing the heat tolerance of 17 beef cattle genotypes. International Journal of Biometeorology, Ohio, v. 54, n. 6, p. 617-627, 2010.

HAHN, G. L. Dynamic responses of cattle to thermal heat loads. Journal of Animal Science, Champaign, v. 77, n. 2, p. 10-12, 1999.

HANSEN, P. J. Physiological and cellular adaptation of zebu cattle to thermal stress. Animal Reproduction Science, Amsterdam, v. 82, n. 1, p. 349-360, 2004.

HOROWITZ, M. From molecular and cellular to integrative heat defence during exposure to chronic heat. Comparative Biochemistry and Physiology Part A: Molecular \& Integrative Physiology, California, v. 131, n. 3 , p. $475-483,2002$.

JOHNSON, S. R.; RAO, S.; HUSSEY, S. B.; MORLEY, P. S.; TRAUB-DARGATZ, J. L. Thermographic eye temperature as an index to body temperature in ponies. Journal of Equine Veterinary Science, Lexington, v. 31, n. 2, p. 63-66, 2011.

MERTENS, D. R. Gravimetric determination of amylase treated neutral detergent fiber in feeds with refluxing in beakers or crucibles: collaborative study. Journal of AOAC International, Hilton, v. 85, n. 6, p. 1212-1240, 2002.

MONTANHOLI, Y. R.; SWANSON, K. C.; PALME, R.; SCHENKEL, F. S.; MCBRIDE, B. W.; LU, D.; MILLER, S. P. Assessing feed efficiency in beef steers through feeding behavior, infrared thermography and glucocorticoids. Animal, Cambridge, v. 4, n. 5, p. 692701, 2010.

O'BRIEN, M. D.; RHOADS, R. P.; SANDERS, S. R.; DUFF, G. C.; BAUMGARD, L. H. Metabolic adaptations to heat stress in growing cattle. Domestic Animal Endocrinology, Beeville, v. 38, n. 2, p. 86-94, 2010.
RENAUDEAU, D.; COLLIN, A.; YAHAV, S.; BASILIO, V.; GOURDINE, J. L.; COLLIER, R. J. Adaptation to tropical climate and research strategies to alleviate heat stress in livestock production. Advances in Animal Biosciences, Cambridge, v. 1, n. 2, p. 378379, 2010.

Adaptation to hot climate and strategies to alleviate heat stress in livestock production. Animal, Cambridge, v. 6, n. 5, p. 707-728, 2012.

SCHÜTZ, K. E.; COX, N. R.; TUCKER, C. B. A field study of the behavioral and physiological effects of varying amounts of shade for lactating cows at pasture. Journal Dairy Science, Madison, v. 97, n. 6, p. 35993605, 2014.

SEJIAN, V.; MAURYA, V. P.; NAQVI, S. M. K. Effect of thermal stress, restricted feeding and combined stresses (thermal stress and restricted feeding) on growth and plasma reproductive hormone levels of Malpura ewes under semi-arid tropical environment. Journal of Animal Physiology and Animal Nutrition, Bogen, v. 95, n. 2, p. 252-258, 2011.

SPRINKLE, J. E.; HOLLOWAY, J. W.; WARRINGTON, B. G.; ELLIS, W. C.; STUTH, J. W.; FORBES, T. D. A.; GREENE, L. W. Digesta kinetics, energy intake, grazing behavior, and body temperature of grazing beef cattle differing in adaptation to heat. Journal of Animal Science, Champaign, v. 78, n. 6, p. 1608-1624, 2000.

THOMPSON, V. A.; FADELAND, J. G.; SAINZ, R. D. Meta-analysis to predict sweating and respiration rates for Bos indicus, Bos taurus, and their crossbreds. Journal of Animal Science, Champaign, v. 89, n. 12, p. 39733982, 2011.

WHEELOCK, J. B.; RHOADS, R. P.; VANBAALE, M. J.; SANDERS, S. R.; BAUMGARD, L. H. Effects of heat stress on energetic metabolism in lactating holstein cows. Journal Dairy Science, Madison, v. 93, n. 2, p. 644-655, 2010. 